\title{
Creative Mathematics Outcomes Achieved by the Junior High School Students as Characteristics of Mathematics Education at St. Paul University
}

\author{
Nikko T. Ederio ${ }^{1}$, Ninia I. Calaca ${ }^{2}$, Sr. Marie Rosanne Mallillin, SPC $^{3}$ \\ ${ }^{1}$ Quality Management Director, St. Paul University Surigao \\ ORCID: 0000-0001-7651-9739 \\ ${ }^{2}$ Research Consultant, St. Paul University Surigao \\ ORCID: 0000-0003-1536-8097 \\ ${ }^{3}$ University President, St. Paul University Surigao \\ ORCID: 0000-0003-4074-1156
}

\begin{abstract}
The study integrated the Charism Core Value of St. Paul University to the Mathematics Subject in Junior High School which is translated into a learning outcome pertaining to becoming a creative, resourceful explorer and problem solver. The junior high school students' achievement of the mathematics learning competencies infused with the Charism core value was determined with the use of researcher-made questionnaires administered to 151 Science Class students enrolled in St. Paul University Surigao during the school year 2019-2020. Data gathered were analyzed using means and standard deviation. As a result, it was determined that the students under study achieved the creative mathematics outcomes and competencies to some extent. As to the specific indicators, the students under study were observed to be doing well at acknowledging points for improvement when solving problems to some extent compared to other indicators as they engaged in their mathematics classes. However, the same students were discovered to be weaker in terms of exhibiting giftedness as they translate mathematical knowledge into meaningful contexts.
\end{abstract}

KEYWORDS: Characteristics of Creative Mathematics Competencies, Mathematics Outcomes and Competencies, OutcomeBased Mathematics Education, Student Achievement

\section{INTRODUCTION}

The Sisters of Paul of Chartres Education Ministry (2018) believes that the integration of values and spirituality in all the educational institutions' processes and programs was always a challenge to all the religious schools. The efforts of integration remain abstract and render the institutions and educators grappling as to what paradigm or scheme must be used to make "how" of integration a reality existentially.

In terms of mathematics education, the contemporary world entails acquisition and embodiment of the so-called 21stcentury skills and capacity where critical thinking and decision-making skills are primarily needed in order to attain sustainable development and proactive technological advancement. Hence, the modern world problems require modern world and innovative solutions. One best way is by teaching the value of critical thinking for good decision making, problem-solving, and risk-taking to the minds and hearts of the modern world learners. This can be achieved through teaching and inculcating the unique or distinct Mathematical discipline teaching.

Mastrangeli (2019) believes that mathematical expertise entails effective thinking and learning strategies transferred well to all domains of the teaching-learning process. Mathematical reasoning and thinking processes generally impact knowledge acquisition and problem-solving.

Examining mathematics teaching in the classroom described by Paulinian students' success in achieving the intended learning outcomes and competencies is very beneficial and significant to Mathematics teachers in schools as this will surely equip them in this era of non-stop curriculum advancement. Moreover, the modern world mathematics requires not only simple knowhow about the subject concepts but also more on the mastery and deeper understanding of the subject leading to learners contextualizing ideas relevant of values and holistic development, applying concepts to real-life situations, realizing and selfevaluating realistic mathematical knowledge absorbed, and creation of actual existence of Mathematical concepts in the 


\section{International Journal of Current Science Research and Review}

ISSN: 2581-8341

Volume 05 Issue 01 January 2022

DOI: 10.47191/ijcsrr/V5-i1-18, Impact Factor: 5.825

IJCSRR@ 2022

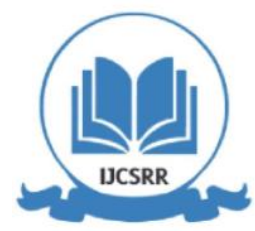

WwW.ijcsrr.org

contemporary world fullof life-changing and affecting scenarios requiring each learner to transform or become critical thinkers and problem solvers (Ederio, et.al., 2021).

This study explained the junior high school students' achieved creative mathematics outcomes and competencies which then mark the characteristics of mathematics education at St. Paul University Surigao and that in the end, the findings will provide support for recommendatory or intervening initiatives intended to improve students' mathematics achievement by improving teachers' pedagogy and values integration techniques. Lastly, this academic output may be able to present ideas to suggest how critical thinking and learning methodology as the main components for efficient contemporary mathematics teaching be attained or achieved successfully.

\section{FRAMEWORK}

The study determined the extent of creative mathematics outcomes and competencies achieved by the Junior High School students as characteristics of mathematics education at St. Paul University Surigao. This was done after integrating the Charism Core Value of St. Paul University to the Mathematics Subject in the Junior High School which was then translated into a general mathematics learning outcome pertaining to becoming creative, resourceful explorer and problem solver. In other words, the study investigated the students' mathematics learning outcomes and competencies achievements derived from the Charism Core Value of St. Paul University alongside the Kto12 Mathematics Education Twin Competency Goals of the Philippines' Department of Education.

Learning Outcome. SPCEM (2018) refers this as a clear statement of what a learner is expected to do, know about, and value at the end of studying which are measurable. It states both the substance of learning and how its attainment is to be demonstrated. It also refers to the SPCEM life performance behaviors intended for all Paulinian learners to achieve as a result of taking up Paulinian education. These outcomes were based on the congregation's Charism core value

Learning Competency. The Department of Education (2016) defined this as the established set of intended skills, behaviors, and knowledge the learners are expected to master.

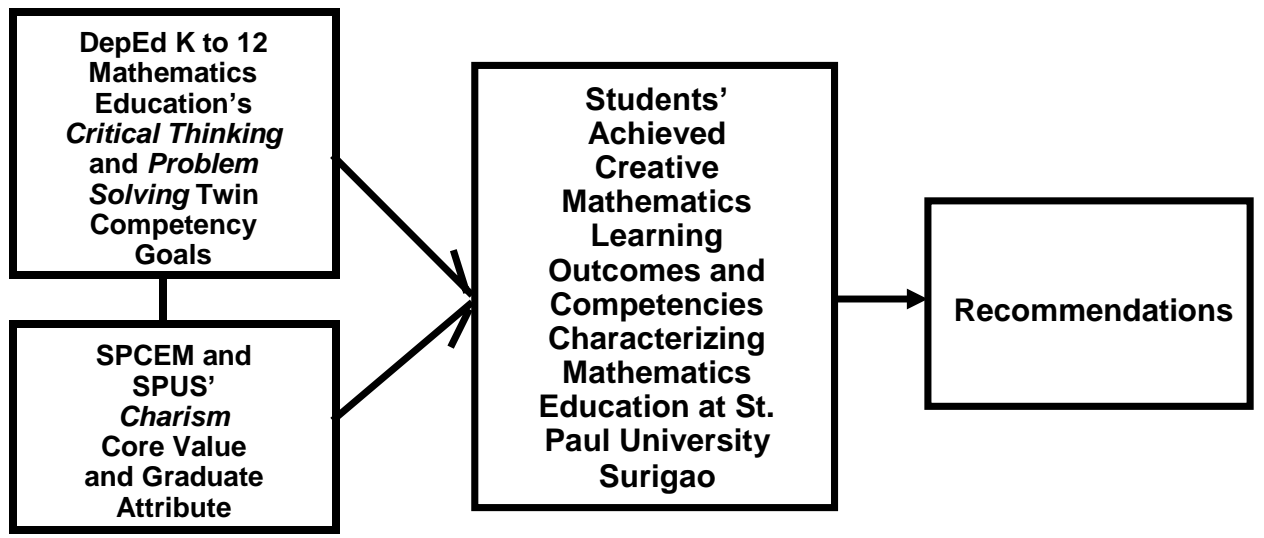

Figure 1. Schematic Diagram of the Study

Figure 1 shows the schematic diagram of the study. As shown, the DepEd Kto12 Mathematics Education Twin Competency Goals namely, Critical Thinking and Problem-Solving Skills are alongside with the SPCEM and SPUS' Charism Core Value and Graduate Attribute which explains that the study intended to join these two major variables to look into the students' achievements in relation to these joined outcomes and competencies which characterized the mathematics education at St. Paul University Surigao. After this, recommendatory initiatives are then intended to be offered.

Scriven and Paul (1987) defined Critical thinking as the intellectually disciplined process of actively and skillfully conceptualizing, applying, analyzing, synthesizing, and/or evaluating information gathered from, or generated by, observation, experience, reflection, reasoning, or communication, as a guide to belief and action.

On the other hand, Polya (1945 \& 1962) stated that mathematical problem solving is finding a way around a difficulty, 


\section{International Journal of Current Science Research and Review}

ISSN: 2581-8341

Volume 05 Issue 01 January 2022

DOI: 10.47191/ijcsrr/V5-i1-18, Impact Factor: 5.825

IJCSRR@ 2022

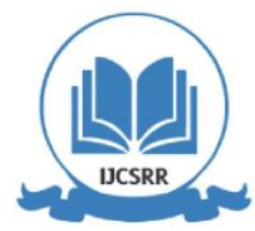

WWW.ijcsrr.org

around an obstacle, and finding a solution to a problem that is unknown. These two goals are to be achieved with organized and rigorous curriculum content, a well-defined set of high-level skills and processes, desirablevalues and attitudes, and appropriate tools, considering the different contexts of Filipino learners.

In terms of pedagogy, Experiential and Situated Learning, Reflective Learning, Constructivism, Cooperative Learning and Discovery, and Inquiry-based Learning are the major teaching-learning strategies the Philippines' mathematics framework emphasized in order to achieve these competency goals.

Experiential Learning theory defines learning as "the process whereby knowledge is created through the transformation of experience. Knowledge results from the combination of grasping and transforming experience" (Kolb, 1984). Situated Learning, as theorized by Lave and Wenger (1991), is learning in the same context in which concepts and theories are applied. Reflective Learning refers to learning that is facilitated by reflective thinking. It is not enough that learners encounter real-life situations. Deeper learning occurs when learners can think about their experiences and process these, allowing them the opportunity to make sense of and derive meaning from their experiences. Constructivism is the theory that argues that knowledge is constructed when thelearner can draw ideas from his/her own experiences and connect them to new ideas. Cooperative Learning puts a premium on active learning achieved by working with fellow learners as they all engage in a shared task. The mathematics curriculum allows students to learn by asking relevant questions and discovering new ideas. Discovery Learning and Inquiry-based Learning (Bruner, 1961) support the idea that students learn when they make use of personal experiences to discover facts, relationships, and concepts.

On the other hand, the SPCEM and SPUS' Charism Core Value and Graduate Attribute explains that one of the aims of the SPC Education Ministry for its Basic Education learners is to let them achievethe intended learning outcomes aligned to the Congregation's Charism core value - "producing young Paulinian citizens who embody the value of CHARISM, the value in which a person is endowed with spiritual talents and giftedness by the Holy Spirit exhibited by being CREATIVE thus becoming CREATIVE, RESOURCEFUL EXPLORER \& PROBLEM SOLVER (SPCEM, 2018).

\section{STATEMENT OF THE PROBLEM}

The study determined the extent of creative mathematics outcomes and competencies achieved by the Junior High School students as characteristics of mathematics education at St. Paul University Surigao. Specifically, this study sought answers to the following questions:

1. To what extent have the creative mathematics learning outcomes and competencies been achieved as perceived by the students under study?

2. Based on the findings, what recommendations can be given?

\section{METHODOLOGY}

\section{Research Design}

In this study, the researcher used a quantitative research design employing a descriptive research survey approach which allowed the researcher to gather more precise and quantifiable information needed to quantify responses that may lead to expected research outcomes with the help of the identified appropriate indicators. Specifically, the study employed mean and standard deviation to determine the extent of creative mathematics outcomes and competencies achieved by the Junior High School students as characteristics of mathematics education at St. Paul University Surigao, perceived by the students themselves.

\section{Participants}

The participants of this study were the Junior High School students at St. Paul University Surigao School Year 2019-2020. Purposive sampling technique was used in this study since it does not need underlying theories or a set number of participants which decisions concerning the individuals to be included in the sample are taken by the researcher. The researcher considered conducting the study only to the 151 Science Class students who enrolled at St. Paul University Surigao during the school year 2019-2020. Only the science class students were consideredin this study since they all had taken both regular and elective mathematics subjects offered by the university.

\section{Data Collecting Instruments}

The main instruments used to solicit information were researcher-made questionnaires. for the Junior High School students. 


\section{International Journal of Current Science Research and Review}

ISSN: 2581-8341

Volume 05 Issue 01 January 2022

DOI: 10.47191/ijesrr/V5-i1-18, Impact Factor: 5.825

Moreover, the questionnaires contained items or indicators that asked primarily for their perceptions on the creative mathematics learning outcomes and competencies achieved bythemselves.

\section{Data Gathering}

The researcher used questionnaires and those were personally administered to the students under study. Before the actual gathering of data, a letter was sent to the Principal of the Basic Education Department of the University asking for the approval to conduct the study to the science class students at the Junior High School. After the approval, the researcher administered the researcher-madequestionnaires to the actual participants. The data were tallied, treated, and interpreted for analysis and discussion.

\section{Ethical Consideration}

In this study, the researcher strictly observed research ethics wherein confidentiality, privacy rights, and safety of the participants as well as the ethical practices of the researcher were strongly observed. Primarily, the researcher adhered to certain provisions applicable under the DPA Act of 2012 to protect the participants and the researcher of the study. The questionnaires of the study integrated Data Privacy consent and waivers for the sake of the security assurance for both researcher and the participants. The researcher also respected the involved persons' feelings and opinions. The researcher ensured that individuals voluntarily participated in the research with full knowledge of relevant risks and benefits through an informed consent. Also, the researcher in this study respected the feelings andpersonal information property rights of the informants. Hence, the confidentiality of information was ensured through the maintenance of privacy.

\section{Data Analysis}

In fulfilling the desire of having most reliable and appropriate results and findings on determining the extent of creative mathematics outcomes and competencies achieved by the Junior High School students as characteristics of mathematics education at St. Paul University Surigao, the researcher used the following statistical tools to analyze the data:

Means and Standard Deviation. These tools were used to quantify the participants' responses to the creative mathematics learning outcomes and competencies achievement perceptions indicators.

The following is a 4-point frequency and extensiveness Likert scale that was used as the basis for the interpretation of data yielded from the responses of the participants of the study in relation to problems 4 and 5:

$\begin{array}{llll}\text { Scale } & \text { Range } & \text { Qualitative Description } & \text { Verbal Interpretation } \\ 4 & 3.25-4.00 & \text { Always } & \text { To Very Much Extent } \\ 3 & 2.50-3.24 & \text { Sometimes } & \text { To Some Extent } \\ 2 & 1.75-2.49 & \text { Rarely } & \text { To Little Extent } \\ 1 & 1.00-1.74 & \text { Never } & \text { To No Extent At All }\end{array}$

Upon statistical treatment, the interpreted data was discussed to infer and elicit proper conclusions and supporting ideas that suited to answer problems number 4 and5 specifically on the extent of achievement of creative mathematics learning outcomes and competencies as perceived by students under study. Participants responded to each indicator in the questionnaires based on their best and honest evaluation signifying their perceptions on the achievement of the creative mathematics learning outcomesand competencies of the students under study. Average responses within $1.00-1.74$ were described as never frequent and meant as to no extent at all; $1.75-2.49$ as rarely frequent and meant as to little extent; $2.50-3.24$ as sometimes frequent and meant as to some extent; and 3.25 - 4.00 as always frequent and meant as to very much extent.

\section{FINDINGS, RESULTS, AND DISCUSSION}

On the Extent of Creative Mathematics Learning Outcomes and Competencies Achieved as Perceived by the Students that Characterized Mathematics Education at St. Paul University Surigao. 


\section{International Journal of Current Science Research and Review}

ISSN: 2581-8341

Volume 05 Issue 01 January 2022

DOI: 10.47191/ijesrr/V5-i1-18, Impact Factor: 5.825

IJCSRR@ 2022

WwW.ijcsrr.org

Table 1. Creative Mathematics learning outcomes and competencies achieved by the students under study

Indicators

Mean SD VI

CRE (Creative, Resourceful Explorer \& Problem Solver / Charism Core Value)

creatively demonstrate resourcefulness upon fulfilling mathematical tasks.

exhibit giftedness as I translate mathematical knowledge into meaningful contexts.

relate prior knowledge to the new concepts and openly accept it as I apply knowledge in real-life 2.91 experiences.

find an alternative or substitute for a learning material/activity to visualize a concept.

accomplish tasks with competence and determination.

exhibit craftsmanship in fulfilling tasks by being skillful, practical, and innovative.

show proficiency in understanding mathematical problems

explore patterns in finding solutions to problems.

illustrate ideas and make decisions when solving problems.

acknowledge points for improvement when solving problems

use imagination to solve problems.

simplify complex tasks by breaking it down into orderly manageable parts.

can exhibit proficiency in solving real-world problems using appropriate learning tools or resources

create options in facing and solving problems

evaluate relevant and creative options in facing and solving problems.

define issues, problems, and opportunities to generate possible solutions to a problem.

evaluate their solutions to problems whether such are best appropriate and applicable or not.

illustrate ideas and scenarios by translating mathematical knowledge from numerical statements into real-world contexts.

can construct new insights from their own experiences and realizations after solving mathematical 2.93 problems
2.84 .731 To Some Extent

$2.70 \quad .781$ To Some Extent

.827 To Some Extent

$2.99 \quad 770 \quad$ To Some Extent

2.93 .784 To Some Extent

$2.89 \quad 818$ To Some Extent

2.81 .778 To Some Extent

$2.96 \quad 832$ To Some Extent

$2.95 \quad 815$ To Some Extent

3.01 .796 To Some Extent

2.94 .881 To Some Extent

2.86 .783 To Some Extent

2.81 .761 To Some Extent

$\begin{array}{lll}2.88 & .832 & \text { To Some Extent }\end{array}$

2.86 .783 To Some Extent

2.93 .758 To Some Extent

$2.99 \quad .774$ To Some Extent

$2.91 \quad .819$ To Some Extent

.767 To Some Extent

\section{Average 2.93 0.618 To Some Extent}

\section{Ratings Scale: Mean \\ $3.26-4.00$ \\ $2.51-3.25$ \\ $1.76-2.50$ \\ $1.00-1.75$}

Qualitative Description
Always
Sometimes
Rarely
Never

\author{
Verbal Interpretation \\ To Very Much Extent \\ To Some Extent \\ To Little Extent \\ No Extent At All
}

Table 1 shows the creative mathematics learning outcomes and competencies achieved as perceived by the students that characterized mathematics education at St. Paul University Surigao. For the students, the said outcomes and competencies in general was achieved to some extent given the average Mean=2.93 andaverage $\mathrm{SD}=0.618$. This means that the students perceived that the students are creative, resourceful explorers \& problem solvers exhibiting the charism core value to some extent as they engaged in their mathematics classes.

Furthermore, Table 1 shows that for the students, they acknowledge points for improvement when solving problems to some extent which is seen as the best and the highest among all indicators obtaining the mean rating of 3.01 and SD=0.796. This implies that the students believed that they acknowledge points for improving when solving problems to some extent as they engaged in their mathematics classes.

The SPC Education Ministry (2018) emphasized that a Paulinian learner mustsearch voluntarily beyond readily available resources of information, resources, and standard techniques to generate new understanding towards workable solutions to existing problems. Moreover, a Paulinian who is expected to embody the creative, resourceful explorer \& problem solver learning outcome 


\title{
International Journal of Current Science Research and Review
}

\author{
ISSN: 2581-8341
}

\section{Volume 05 Issue 01 January 2022}

DOI: 10.47191/ijcsrr/V5-i1-18, Impact Factor: 5.825

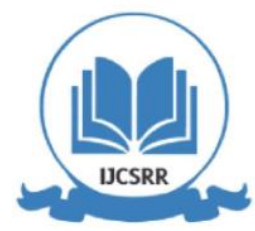

WWw.ijesrr.org

exhibiting the charism core value uses original ideas to create solutions to existing problems.

The Department of Education (2016) also underscores that educators, the curriculum, and the content must always include and ascertain transfer oflearning to sustain and apply knowledge in the real world or context and so provide meaningful learning for learners across all levels in all subjects by effective means of assessment (Cree \& Macaulay, 2000). One of the primary competencies the mathematics education framework intends to all Kto12 learners to attain this transfer of learning is thatthe learners must demonstrate the capacity and skill on illustrating mathematical problems and translating numerical statements into real-world problems and vice versa. Ultimately, the Kto12 Mathematics Education Framework of the Philippines emphasized that the learners must be able to demonstrate the skill of problem-solving, posing and solving his or her problem, and be able to validate and review his or her solutions whether such are accurate or otherwise (DepEd,2016).

Looking closely to the lowest result, the students believed that they are weaker in terms of exhibiting giftedness as students translates mathematical knowledge into meaningful contexts depicted by the obtained lowest mean rating of $2.70, \mathrm{SD}=0.781$, and verbally interpreted To Some Extent. This implies that the students believed that they have exhibited giftedness as they translate mathematical knowledge into meaningful contexts to some extent as they engaged in their mathematics classes.

Singh and $\mathrm{Yu}$ (2018) made mention that what makes mathematics a commonly difficult subject to most of the learners is because of its problem solving, reasoning, and critical thinking aspects which most of the learners cannot easily possess or develop. Additionally, most of the mathematics learners are limited only to how the problems are solved as demonstrated by the teacher who may not demonstrate ample mastery of the process for solving the problem. Consequently, the students cannot cope with the individual techniques of the teacher thus leaving them unable to find solutions or solving processes on their own.

Khair \& Khairani (2012) also stated that students suffering from difficulties in mathematics at all levels are noticeable. The students cannot easily come out with problem solutions because of related problems with reasoning and the ability to translate mathematical problems into solvable equations.

Giftedness refer to students having gifts and talents to perform or execute at higher levels compared to others (Steinmeyer, 2020). Specificlly, intellectual giftedness is anintellectual ability significantly higher than average (Mackintosh, 2011).

In the context of the Paulinian education, a Paulinian must work hard to develop his or her God-given talents for the love of God in the service of the Church, family, and community. He or she also is open to new inputs, suggestions, and knows how to adjust performances and welcomes new learning in different situations. Moreover, a creative Paulinian stands out for his or her uniqueness and originality and that he or she accomplish-es tasks with determination. A creative Paulinian shares his or her talents and resources most especially to those in most need and shall be able to inspire others to do their best, using his or her highest potential in any performances. In relation, a gifted Paulinian performs excellently in his or her studies, projects, and assigned tasks and further assists in the development and empowerment of others (SPCEM, 2018).

Ederio, et. al (2021) emphasized that a Paulinian who is a problem solver and a critical thinker makes the good and right decision in his or her choices and in solving problems. Being a critical thinker too, a Paulinian stands for the truth regardless of criticism or non-acceptance of others of his or her choices and in solving problems. Furthermore, a resourceful and gifted explorer Paulinian uses original ideas to create solutions to existing problems performing excellently in his or her studies, projects, and assigned tasks and further assists in the development and empowerment of others.

Khair \& Khairani (2012) stressed that it is noticeable that students are suffering from difficulties in mathematics at all levels. To improve the mathematics teaching and raise students' achievement level in mathematics is to rehabilitate the teacher of mathematics and provide him/her with educational training programs, upgrade his/her level academically and professionally through the educational supervision services. Schools and academicians should consider focusing on detecting mathematics teaching difficulties and examining the mathematics teaching strategies and methods of evaluation employed in teaching mathematics.

Teachers normally focus on developing students' procedural skills rather than the cognitive and contextual aspects particularly in the area of Mathematics. The mathematics class is based on direct instruction where teachers review mathematical concepts, present the procedures required to solve tasks, and then have students practice these procedures with traditional problems (Hiebert \& Grouws, 2007).

Values integration and even spirituality promotion are some of the hardest methods to interject and integrate with mathematical knowledge in all schools. Values integration and even spirituality promotion are not always the easiest to integrate 


\section{International Journal of Current Science Research and Review}

ISSN: 2581-8341

Volume 05 Issue 01 January 2022

DOI: 10.47191/ijesrr/V5-i1-18, Impact Factor: 5.825

IJCSRR@ 2022

WWW.ijcsrr.org

with Mathematics. Values seem to receive the least attention although it is one of the most stable affective domains (Ederio, et. al, 2021).

\section{CONCLUSIONS}

Based on the findings of the study, the following conclusions were drawn:

1. The students' achieved creative mathematics learning outcomes and competencies are indeed one of the characteristics of mathematics education at St. Paul University Surigao. This was reaffirmed after interconnecting and jiving the Department of Education's Mathematics Education Twin Competency Goals and the SPCEM \& SPU Surigao's Charism Core Value leading to the creation of distinct mathematics learning outcomes and competencies for the Paulinian school.

2. The mark of Paulinian Education in St. Paul University Surigao Junior High Schoolis its commitment and consistent implementation of Paulinian Spirituality and Holistic Excellence as emphasized by outcomes-based mathematics teaching.

\section{RECOMMENDATIONS}

Based on the findings and conclusions of this study, the following recommendations are offered:

1. That the findings of this study will be presented to the Junior High School of the University. The essence and truth shown by this study will give the teachers and students a glimpse of how the learners are achieving in the mathematics subject in terms of the creativity aspect of mathematics education.Moreover, the results of this study can give them the generalized picture of the extent of their achievements in mathematics relative to charism Paulinian core value or the creativity aspect of mathematics learning outcomes and competencies at St. Paul University Surigao.

2. That St. Paul University Surigao Academic coordinators consider the significant findings of this study in planning and implementing faculty training and development programs for mathematics teachers focusing on the Outcome-based Education emphasizing the characteristics of Paulinian Mathematics Education.

\section{REFERENCES}

1. Bruner, J. S. (1961). The act of discovery. Harvard Educational Review, 31, 21-32.

2. Cree, V., \& Macaulay, C. (Ed.) (2000). Transfer of Learning in Professional and Vocational Education. Routledge.

3. Department of Education (2016). The Conceptual Framework of Mathematics Education in the Philippines. Department of Education of the Republic of the Philippines. Retrieved from http://depedbohol.org/v2/wp-content/uploads/2016/03/Math-CG_with-tagged-math-equipment.pdf

4. Ederio, N., Mallillin, M.R., Andrin, G., Calaca, N, Watin, A.K., Palijo, H.S.T., ... Guilalas, A.V. (2021). Characterizing Outcomes-Based Mathematics Teaching: Mark of Paulinian Education. European Scholar Journal, Volume 2(No. 11), 122. https://doi.org/10.5281/zenodo.5701558

5. Ederio, N., Calaca, N., \& Malllillin, M.R.. (2021). Extent of mathematics learning outcomes and competencies achieved by the junior high school students of St. Paul University. Review of International Geographical Education Online, Volume 10 (No. 11), 1-26. https://doi.org/10.5281/zenodo.5830884

6. Khair, T.M.A.M., \& Khairani, (2012). Level of students' achievement in mathematics at the end of elementary education in Yemen. Englewood Cliffs, N.J: Prentice-Hall.

7. Mackintosh, N. J. (2011). IQ and Human Intelligence (second ed.). Oxford: Oxford University Press. ISBN 978-0-19958559-5. LCCN 2010941708. Retrieved 15 June 2014.

8. Mastrangeli, J., (2019). Beyond the Classroom: Mathematics in Service. Journal of Humanistic Mathematics. Jul2019, Vol. 9 Issue 2, p212-225. 14p.

9. Polya, G. (1945). How to solve it; a new aspect of mathematical method. Princeton University Press.

10. Scriven, M. and Paul, R. (1987) Defining Critical Thinking. 8th Annual International Conference on Critical Thinking and Education Reform. http://www.criticalthinking.org/pages/defining-critical-thinking/766

11. Sisters of Paul of Chartres Education Ministry, P.P. (2018). "Mainstreaming interculturality in paulinian education: paulinian formation program". Pasig City, Philippines.

12. Steinmeyer, P. (2020). Supporting Advanced Learners: New Roles for Parent Advocates During Times of Remote Learning. 


\section{International Journal of Current Science Research and Review}

ISSN: 2581-8341

Volume 05 Issue 01 January 2022

DOI: 10.47191/ijesrr/V5-i1-18, Impact Factor: 5.825

IJCSRR@ 2022

WwW.ijesrr.org

National Association for Gifted Children. Retrieved from: https://www.nagc.org/blog/supporting-advanced-learners-newroles-parent-advocates-during-times-remote-learning.

13. Yu, R., \& Singh, K., (2018). Teacher support, instructional practices, student motivation, and mathematics achievement in high school. Journal of Educational Research. 2018, Vol. 111 Issue 1, p81-94. 14p.

Cite this Article: Nikko T. Ederio, Ninia I. Calaca, Sr. Marie Rosanne Mallillin, SPC (2022). Creative Mathematics Outcomes Achieved by the Junior High School Students as Characteristics of Mathematics Education at St. Paul University. International Journal of Current Science Research and Review, 5(1), 156-163

$163{ }^{*}$ Corresponding Author: Ninia I. Calaca2, Sr. Marie Rosanne Mallillin, SPC Volume 05 Issue 01 January 2022 